\title{
Effect of organic compost manufactured with vegetable waste on nutrient supply and phytotoxicity
}

\author{
Eui Yeong Kim ${ }^{1}$ Young Kyu Hong ${ }^{1}$ Chang Hoon Lee ${ }^{2}$. \\ Taek Keun $\mathrm{Oh}^{1} \cdot$ Sung Chul Kim ${ }^{1}$ (B)
}

Received: 25 June 2018/ Accepted: 15 July 2018/Published online: 26 July 2018

(C) The Korean Society for Applied Biological Chemistry 2018

\begin{abstract}
The amount of vegetable waste (VW) has increased, and demand for good quality of organic soil amendment is high. For these reasons, successive composting technique was tried to examine the possibility of increasing nitrogen contents in the compost. Collected VW was initially composted after mixing with either sawdust (SD) or cocopeat (CP) at different ratios (30-50\% of SD or $\mathrm{CP})$. After finishing the first composting cycle, finished compost was mixed with fresh VW at various ratios (10-30\% of VW) for the second cycle of composting. Temperature, $\mathrm{pH}$, electrical conductivity (EC), organic matter $(\mathrm{OM})$ content, and carbon/nitrogen ratio $(\mathrm{C} / \mathrm{N}$ ratio) were monitored, and compost maturity, phytotoxicity, nutrient contents and heavy metal concentration of the final compost in the second cycle of composting were measured. Temperature profiles of the first and second composts showed typical composting processes, and temperature was increased up to the range of $55-68{ }^{\circ} \mathrm{C}$ in both the first and second compost during the thermophilic period. Other chemical properties such as $\mathrm{pH}$ (6.60-9.10), EC (1.36-2.86 $\mathrm{dS} \mathrm{m}^{-1}$ ), and OM content (49.40-64.04\%) were within the ranges of typical composts. The nitrogen content (1.76-2.28\%) was increased when successive composting technique was adapted. After finishing the second composting, average nitrogen content was increased at the range of 9.4-32.4\% compared to the first
\end{abstract}

Sung Chul Kim

sckim@cnu.ac.kr

1 Department of Bio-Environmental Chemistry, Chungnam National University, Daejeon 34134, Republic of Korea

2 Soil and Fertilizer Division National Academy of Agricultural Science, Rural Development Administration, Wanju 55365, Republic of Korea cycle of compost. The maturity test showed that all the composts satisfied criteria of maturity level and concentration of hazardous heavy metal was below the threshold value in Korea. In conclusion, VW could be recycled to make organic soil amendment and successive composting process is an efficient technique to increase the nitrogen contents in the compost.

Keywords Composting $\cdot$ Nutrients $\cdot$ Phytotoxicity $\cdot$ Soil amendment $\cdot$ Vegetable waste

\section{Introduction}

The amount of food waste is continuously increasing as a result of population growth and increased rate of food consumption [1]. Igalavithana et al. [2] reported that around $30 \%$ of food is wasted in worldwide and emission rate of food waste in Korea is about 15,340 tons per day which accounts for $29.9 \%$ of municipal waste emissions [3]. Vegetable waste (VW) is one of food waste, and emission rate of VW in Korea is 245 tons per day occupying $1.6 \%$ of food waste emission [4].

Since the Ministry of Environment of Korea prohibited landfill of food waste from 2005, about $94.4 \%$ of food waste is recycled into compost, animal feed, biogas, etc. Traditional way to manage organic waste such as landfill and incineration can cause water and air pollution, but recycling of the organic waste as soil amendments can minimize environmental pollution. Composting is one of the prevalent methods to manage organic wastes including municipal solid waste, livestock manure, and food waste $[5,6]$. Composting is a biochemical process that converts organic substances into amendments through microbial 
decomposition under aerobic conditions. Epstein [7] mentioned that application of compost can improve soil conditions and crop productivity. Also, Forte et al. [8] studied that compost can be an efficient tool to sequestrate $\mathrm{CO}_{2}$ as soil carbon and mitigate soil GHG emission in agricultural ecosystem. VW also has an advantage for making organic amendments because of high nutrient contents and low hazardous pollutants $[9,10]$.

In order to make compost with organic waste, several factors should be considered. Vallini et al. [11] reported that aeration system is important to prevent appearance of anaerobic microorganisms producing phytotoxic metabolites in the compost. Zhang et al. [12] and Yu et al. [13] studied physicochemical properties and microbial community of the compost and concluded that physicochemical parameters, such as compost pile temperature, water soluble carbon, nitrogen content, and moisture content (MC), have a significant influence on the microbial community during VW composting. Rawoteea et al. [14] also mentioned that the bulking agent and property of the composting substrate are crucial factors and should be taken into account prior to composting.

Different techniques can be applied to manage organic waste. Recent study applied different techniques for composting, co-ensiling, co-composting, and anaerobic co-digestion, to manage crop residuals. This study compared three different techniques for composting in terms of soil mineralization after application in soil and concluded that application of silages in soil resulted high $\mathrm{C}$ mineralization rates, while compost and digestate application led to lower $\mathrm{C}$ mineralization rate and microbial biomass $\mathrm{C}$ in soil. Especially, composting had an effect on lowering mineralization of $\mathrm{C}$, decreasing risk of $\mathrm{N}$ leaching, and helping to increase top soil C [15].

Most of the recent compost studies tried to utilize different organic wastes and bulking agents for enhancing compost quality. However, study about new techniques such as multiple steps of composting or successive composting with same organic materials is limited. The aim of this study was to evaluate a feasibility of successive composting technique with $\mathrm{VW}$ for producing organic amendments and also to examine successive composting technique with VW which can increase the nitrogen contents in the final compost.

\section{Materials and methods}

\section{Compost materials}

VW was collected from a waste treatment facility of the vegetable market in the city of Daejeon, Korea. Fresh VW sample chopped into pieces, dewatered, and stored in a storage tank was collected using a shovel and placed in a 20L sample bag. The collected VW sample was transported to the greenhouse and thoroughly mixed for homogenization. Two different organic substrates, sawdust (SD) and cocopeat $(\mathrm{CP})$, were commercially available and purchased from a local market.

\section{Compost reactor}

The compost reactors had dimensions of $36 \mathrm{~cm} \times 60$ $\mathrm{cm} \times 30 \mathrm{~cm}(\mathrm{~W} \times \mathrm{L} \times \mathrm{H})$, and total volumes were approximately 60 L (Fig. 1). An air supplier (MA-200, Wave Point ${ }^{\circledR}$ Technology, USA) was installed at the bottom of each reactor, and the airflow rate was maintained at $1.67 \mathrm{~L} \mathrm{~min}^{-1}$. Air was continuously injected into the reactors, and the cover was perforated with the size of $10 \mathrm{~mm}$ diameter for air and gas ventilation. A temperature sensor (Em50, Decagon Devices, USA) was installed at a depth of $15 \mathrm{~cm}$ above from the bottom of each reactor and programmed to take a measurement at every $4 \mathrm{~h}$.

\section{Compost experimental setup}

The first set of composting was conducted with three different ratios $\left(70: 30,60: 40\right.$, and 50:50\% $\left.\mathrm{w} \mathrm{w}^{-1}\right)$ between VW and bulking agent (SD or $\mathrm{CP}$ ) considering MC of the compost. After adding adequate amount of VW and bulking agents in each reactor (Table 1), materials were thoroughly mixed for complete homogenization. Each compost mixture was turned and thoroughly mixed at every 5 days to ensure sufficient aeration in the reactors. The first compost experiment continued for 35 days until the inner temperature of the compost reached steady state.

After finishing the first experiment, a second set of experiment was conducted by adding fresh $\mathrm{VW}$ on the final compost of the first experiment. Based on MC (less than $65 \%$ ) of the finished compost from the first experiment, final compost of reactor 1-4 and 1-6 for SD and CP mixture was used as main organics and fresh VW was used as

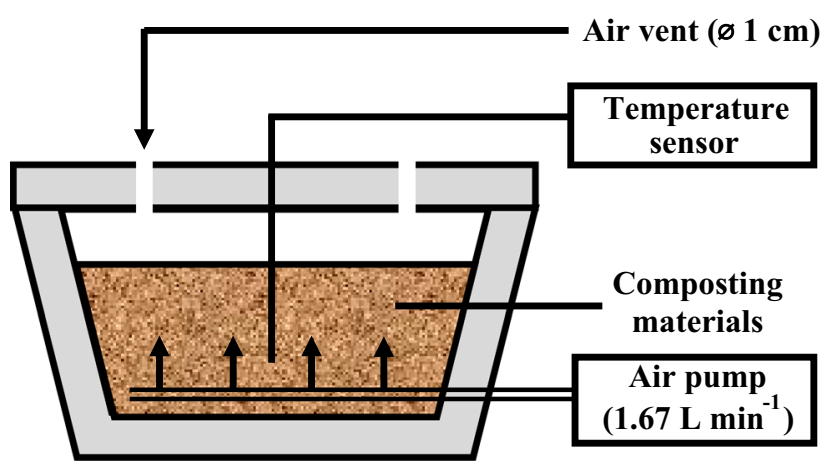

Fig. 1 Schematic diagram of a composting reactor 
Table 1 Compost mixing ratios between the VW and organic substrates

\begin{tabular}{|c|c|c|c|c|c|c|}
\hline \multirow[t]{2}{*}{ Composting cycle } & \multirow[t]{2}{*}{ Reactor No. } & \multirow[t]{2}{*}{ Treatment } & \multicolumn{4}{|l|}{ Mixing ratio (\%) } \\
\hline & & & Vegetable waste (VW) & 1st Cycle product & Sawdust (SD) & Cocopeat $(\mathrm{CP})$ \\
\hline \multirow[t]{7}{*}{$\begin{array}{l}\text { 1st Composting } \\
\text { cycle }\end{array}$} & $1-1$ & $\begin{array}{l}\text { VW } 100 \\
\text { (control) }\end{array}$ & 100 & & & \\
\hline & $1-2$ & VW70 + SD30 & 70 & & 30 & \\
\hline & $1-3$ & VW60 + SD40 & 60 & & 40 & \\
\hline & $1-4$ & VW50 + SD50 & 50 & & 50 & \\
\hline & $1-5$ & VW70 + CP30 & 70 & & & 30 \\
\hline & $1-6$ & VW60 + CP40 & 60 & & & 40 \\
\hline & $1-7$ & VW50 + CP50 & 50 & & & 50 \\
\hline \multirow[t]{7}{*}{$\begin{array}{l}\text { 2nd Composting } \\
\text { cycle }\end{array}$} & $2-1$ & $\begin{array}{l}\text { 1st Product } 100 \\
\text { (control) }\end{array}$ & & 100 & & \\
\hline & $2-2$ & SDC $90+$ VW 10 & 10 & 90 & & \\
\hline & $2-3$ & SDC $80+$ VW 20 & 20 & 80 & & \\
\hline & $2-4$ & SDC $70+$ VW 30 & 30 & 70 & & \\
\hline & $2-5$ & CPC $90+\mathrm{VW} 10$ & 10 & 90 & & \\
\hline & $2-6$ & CPC $80+\mathrm{VW} 20$ & 20 & 80 & & \\
\hline & $2-7$ & CPC $70+V W 30$ & 30 & 70 & & \\
\hline
\end{tabular}

feeding materials. No other bulking agents, SD or CP, were used, and different mixing ratios between final compost in the first cycle of composting and fresh VW (90:10, 80:20, and $70: 30 \mathrm{w} \mathrm{w}^{-1}$ ) were evaluated in the second cycle of composting. The second set was also conducted for 35 days in the same manner as the first set of experiment. From each reactor, samples for measuring MC and chemical properties were collected every 5 days (same day as compost turning) and kept at $4{ }^{\circ} \mathrm{C}$ until analysis. When MC was below $50 \%$, water was added in the reactor to maintain the MC between 55 and $70 \%$.

\section{Chemical analysis}

The chemical analysis for the compost samples was followed by the "Analytical method for a compost" from the RDA (Rural Development Administration) in Korea. Briefly, $2.5 \mathrm{~g}$ of sample was thoroughly mixed with $25 \mathrm{~mL}$ of deionized water $\left(1: 10 \mathrm{w} \mathrm{v}^{-1}\right)$ for $1 \mathrm{~h}$ and the $\mathrm{pH}$ and electrical conductivity (EC) were measured with a $\mathrm{pH}$ meter (MP 220, Mettler Toledo, Switzerland) and EC meter (S230, Mettler Toledo, Switzerland). MC was determined after $20 \mathrm{~g}$ of sample was oven-dried at $105{ }^{\circ} \mathrm{C}$ for $8 \mathrm{~h}$. A $10 \mathrm{~g}$ subsample of this oven-dried sample was heated to $650{ }^{\circ} \mathrm{C}$ for $2 \mathrm{~h}$ in a muffle furnace to determine the organic matter content via a loss on ignition method. Total nitrogen (TN) and total carbon were measured using an elemental analyzer (EA; EA1112, Thermo Fisher Scientific, MA, USA) after $1.0 \pm 0.1 \mathrm{mg}$ of a compost sample was weighed and enclosed in a tin capsule. The temperature in the EA was set to $1000{ }^{\circ} \mathrm{C}$, and the flow rate of the carrier gas $\left(\mathrm{He}, \mathrm{O}_{2}\right.$, and air) was $0.12 \mathrm{~L} \mathrm{~min}^{-1}$. The total concentration of heavy metals (Total $\mathrm{Pb}, \mathrm{Ni}, \mathrm{Cu}, \mathrm{Zn}, \mathrm{As}$, $\mathrm{Cr}, \mathrm{Cd}$ ) in final compost was determined by inductively coupled plasma optical emission spectrometer (ICP-OES, Icap 7000, Thermo fisher scientific). Extraction was carried out with an initial mass of $1.0 \pm 0.1 \mathrm{~g}$ of oven-dried compost samples in 150-mL Teflon digestion tube (OD-98, ODlab, Seoul, Korea). The samples are soaked in $10 \mathrm{~mL}$ of $60 \%$ conc. $\mathrm{HNO}_{3}$ for $24 \mathrm{~h}$ in the tube and heated on the graphite heating block at $150{ }^{\circ} \mathrm{C}$ for $3 \mathrm{~h}$. After heating, $20 \mathrm{~mL}$ of ternary solution $\left(\mathrm{HNO}_{3}: \mathrm{H}_{2} \mathrm{SO}_{4}: \mathrm{HClO}_{4}\right)$ was added in the tube and sample was digested at $150{ }^{\circ} \mathrm{C}$ for $2 \mathrm{~h}$, filtered through $0.45-\mu \mathrm{m}$ filter paper, and filtrate was subjected to ICP-OES for measuring heavy metal concentration.

\section{Compost maturity measurement}

Two different compost maturity tests, a mechanical test and a germination test for examining phytotoxicity, were conducted to analyze the maturity of the final composting products. The commercially available mechanical test Solvita ${ }^{\circledR}$ and the germination test were conducted according to United State Composting Council method [16]. For the Solvita ${ }^{\circledR}$ maturity test, wet compost samples were inserted in a Solvita jar for $4 \mathrm{~h}$ at room temperature 
$\left(20-25{ }^{\circ} \mathrm{C}\right)$ and $\mathrm{CO}_{2}$ and $\mathrm{NH}_{3}$ were measured using gel probes [17].

For the germination test, $1.0 \pm 0.1 \mathrm{~g}$ of finished compost sample was thoroughly mixed with $50 \mathrm{~mL}$ of DI water in a heated water bath at $80{ }^{\circ} \mathrm{C}$ for $2 \mathrm{~h}$. The extract was cooled at ambient temperature $\left(25^{\circ} \mathrm{C}\right)$, filtered with 0.45 $\mu \mathrm{m}$ filter paper, and $5 \mathrm{~mL}$ of filtrate was pipetted into a petri dish $(90 \mathrm{~mm}$ diameter) containing 30 radish seeds (Raphanus sativus L.). The germination test was conducted in a growth chamber at $30{ }^{\circ} \mathrm{C}$ for 5 days under dark conditions. Root length and germination rate were determined in order to calculate the germination index (GI) using the following equations.

$\mathrm{RGR}=($ Germination rate/Germination rate of control $)$

$\times 100$

$\mathrm{RRE}=($ Root extension/Root extension of control $)$

$\times 100$

$\mathrm{GI}=(\mathrm{GR} \times \mathrm{RE})$

where $\mathrm{RGR}=$ relative germination rate, $\mathrm{RRE}=$ relative root extension, and GI = germination index.

\section{Data and statistical analysis}

All measurements were taken in triplicate, and the average values were employed for one-way analysis of variance (ANOVA). Least significance difference was calculated at $p<0.05$ using SPSS ver. 22.0. In addition, bivariate correlation analysis was conducted to evaluate the relationships between the chemical properties and maturity of the final compost.

\section{Results and discussion}

\section{Changes in temperature and moisture content}

The temperature variations of each reactor for the first and second compost cycles are shown in Fig. 2. Temperature profiles of all the reactors except the control showed a similar trend. For both the SD and CP mixtures, the peak temperatures, 65 and $64{ }^{\circ} \mathrm{C}$, were observed when $30 \%$ of bulking agents was mixed with VW. According to temperature profiles, four phases, namely mesophilic, thermophilic, cooling, and maturation, can be classified depending on temperature variance during composting [18]. In general, when the temperature range is between 52 and $60{ }^{\circ} \mathrm{C}$, the compost is considered to be in an active thermophilic state and the temperature needs to be maintained for decomposition and stabilization of organic contents in the compost $[18,19]$. In our study, all the reactors reached thermophilic state within 3-7 days after starting of composting, and it lasted 4-10 days depending on the organic and mixing ratio in the first cycle. The longest thermophilic state ( 7 days) was observed when VW was mixed with $30 \% \mathrm{SD}$, while the shortest thermophilic state (4 days) was observed when the VW was mixed with $40 \%$ CP.

When comparing the two bulking agents, $\mathrm{SD}$ and $\mathrm{CP}$, in terms of temperature increase and maintenance of the thermophilic state, SD showed larger temperature increase and longer thermophilic state maintenance than CP. Results of a Duncan multiple range test showed that the temperature variations in the SD mixtures were significantly higher $(p<0.05)$ than in the CP mixtures (Table 2). One of the reasons for the difference of temperature profile between $\mathrm{SD}$ and $\mathrm{CP}$ can be MC. As MC increases, the gas diffusion rate decreases and, consequently, oxygen uptake becomes insufficient in the system Mohammad et al. [20]. As shown in Fig. 3, the MC from the SD treatment was lower than that from the CP treatment. Bernal et al. [21] also studied the effect of MC on composting efficiency and concluded that $50-60 \% \mathrm{MC}$ is adequate for composting.

For the second compost cycle, the temperature profiles differed from those of the first cycle (Fig. 2 B, D). Temperature increase in the second cycle was faster than that of the first cycle, and the thermophilic state was observed at 3-5 days after beginning of the second composting compared to 4-10 days for the first cycle. Much shorter mesophilic and thermophilic states, but longer cooling and maturation states, were observed. Because no organic substrates were mixed in the second cycle, it can be assumed that the lignin content was much lower than in the first cycle, resulting in much shorter mesophilic and thermophilic states in the second cycle [14].

\section{Change of $\mathrm{pH}$ and $\mathrm{EC}$ in the composts}

The variations of $\mathrm{pH}$ for both the first and second cycles of each reactor are shown in Fig. 4. For the first cycle of composting, the initial $\mathrm{pH}$ of all the reactors was acidic $(\mathrm{pH}$ 4.60-4.96), because of the acidic nature of the original materials (Table 3). A gradual increase in $\mathrm{pH}$ was observed up to 25 days for all reactors, and the highest $\mathrm{pH}$ values of 8.42 and 8.52 were observed in the reactor of $1-2$ and 1-5 (Fig. 4 A, C). For both the SD and CP mixtures, higher $\mathrm{pH}$ was measured as the mixing ratio of $\mathrm{VW}$ increased. Petric et al. [22] and Rawoteea et al. [14] reported that $\mathrm{pH}$ of compost manufactured with organic materials tends toward neutral initially and increased to alkaline due to conversion of acidic materials to carbon dioxide by microbial activity. Our result was agreed to the previous study showing increased $\mathrm{pH}$ as composting was processed. Another reason for increasing $\mathrm{pH}$ of the compost can be explained that 
(A)

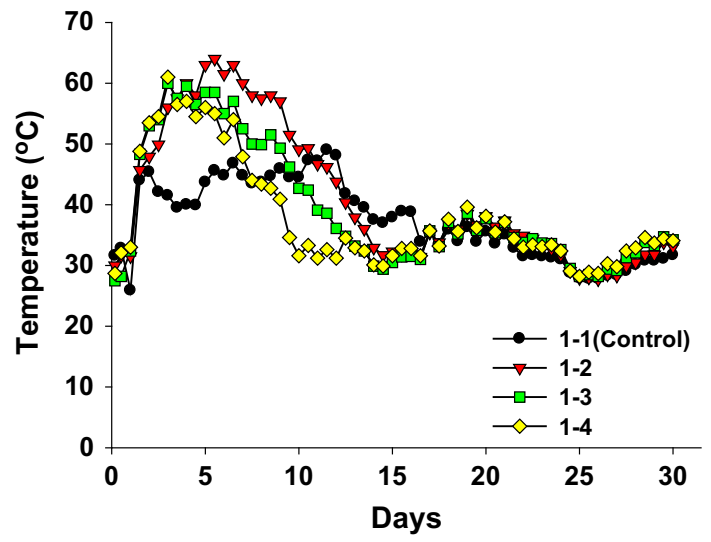

(C)

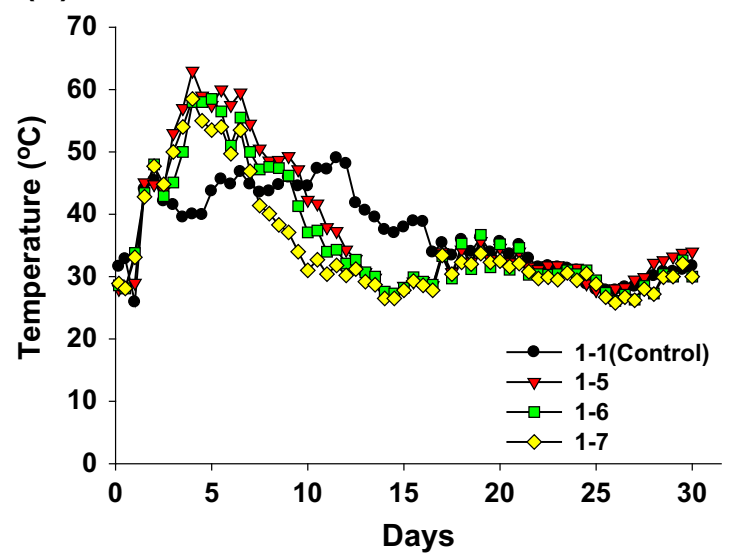

(B)

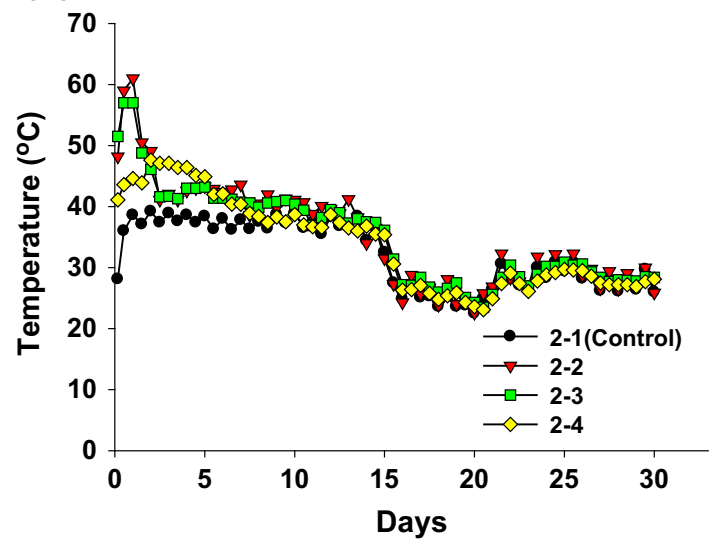

(D)

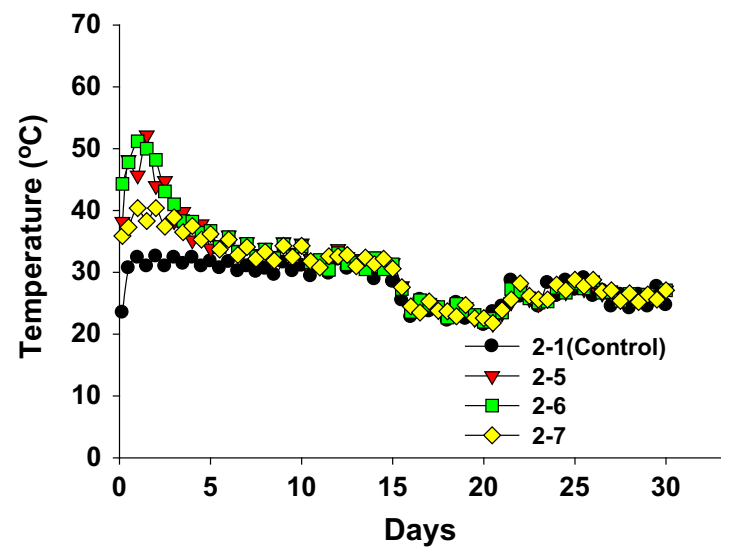

Fig. 2 Temperature profiles during successive VW composting cycles. (A) 1st cycle with SD, (B) 2nd cycle with SD, (C) 1st cycle with CP, (D) 2nd cycle with CP

Table 2 Single-factor ANOVA and multiple range test results of temperature variations during the first and second composting cycles

\begin{tabular}{|c|c|c|c|c|c|c|}
\hline \multirow[t]{2}{*}{ Composting process } & \multirow{2}{*}{$\begin{array}{l}\text { ANOVA } \\
\text { F statistic }\end{array}$} & \multirow[b]{2}{*}{$p$ value } & \multicolumn{4}{|c|}{ Multiple range test } \\
\hline & & & Reactor No. & Mean & $\mathrm{N}$ & $\begin{array}{l}\text { Duncan } \\
\text { grouping }^{\mathrm{a}}\end{array}$ \\
\hline \multirow[t]{7}{*}{ 1st Composting } & \multirow[t]{7}{*}{7.263} & \multirow[t]{7}{*}{$0.000 * *$} & $1-1$ & 37.19 & 181 & $a b$ \\
\hline & & & $1-2$ & 40.89 & 181 & $\mathrm{~d}$ \\
\hline & & & $1-3$ & 39.32 & 181 & $\mathrm{~cd}$ \\
\hline & & & $1-4$ & 37.89 & 181 & $\mathrm{bc}$ \\
\hline & & & $1-5$ & 37.78 & 181 & $\mathrm{bc}$ \\
\hline & & & $1-6$ & 36.80 & 181 & $a b$ \\
\hline & & & $1-7$ & 35.18 & 181 & $\mathrm{a}$ \\
\hline \multirow[t]{7}{*}{ 2nd Composting } & \multirow[t]{7}{*}{29.534} & \multirow[t]{7}{*}{$0.000 * *$} & $2-1$ & 29.95 & 181 & $\mathrm{a}$ \\
\hline & & & $2-2$ & 33.78 & 181 & $\mathrm{~b}$ \\
\hline & & & $2-3$ & 34.77 & 181 & $\mathrm{~b}$ \\
\hline & & & $2-4$ & 35.22 & 181 & $\mathrm{~b}$ \\
\hline & & & $2-5$ & 29.81 & 181 & $\mathrm{a}$ \\
\hline & & & $2-6$ & 30.66 & 181 & $\mathrm{a}$ \\
\hline & & & $2-7$ & 30.47 & 181 & $\mathrm{a}$ \\
\hline
\end{tabular}

$* p<0.05, * * p<0.01$, Duncan multiple range test result: treatments with differing alphanumeric designations are significantly different in their mean values 
(A)

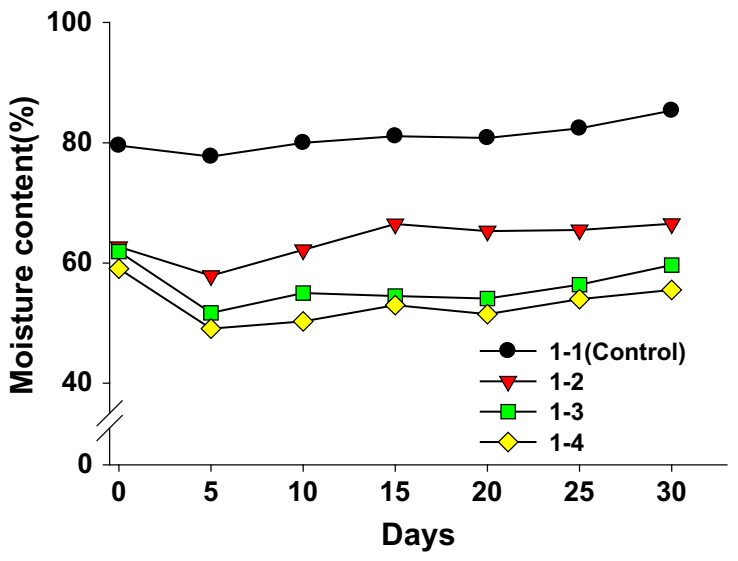

(C)

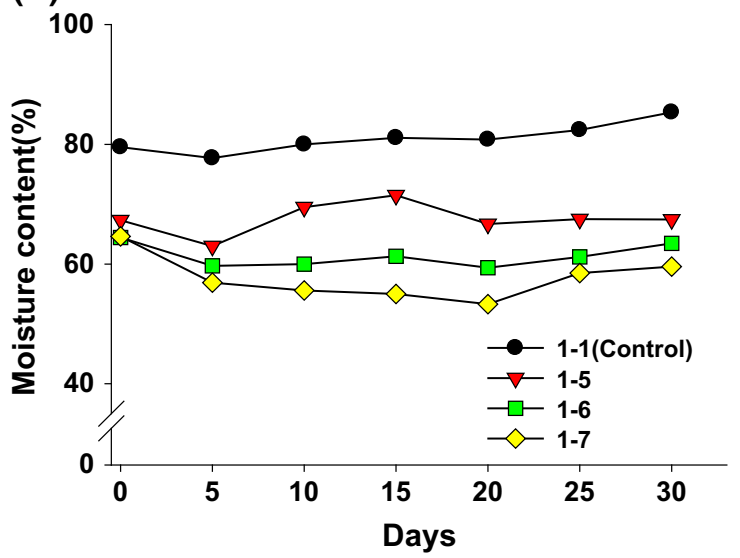

(B)

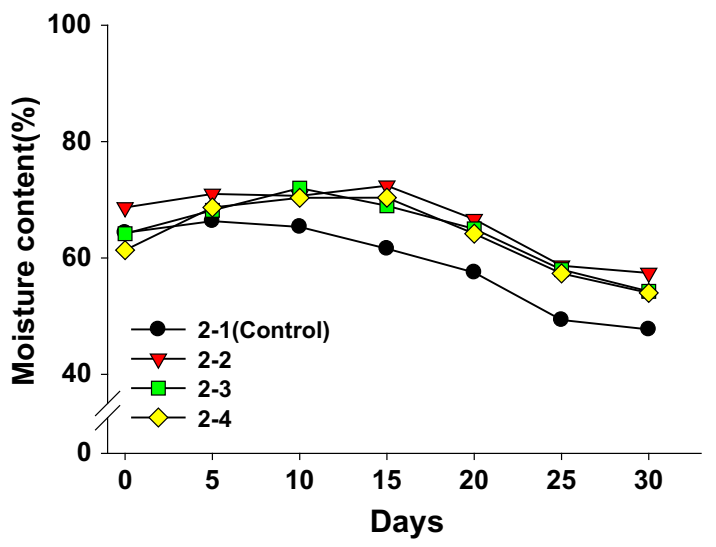

(D)

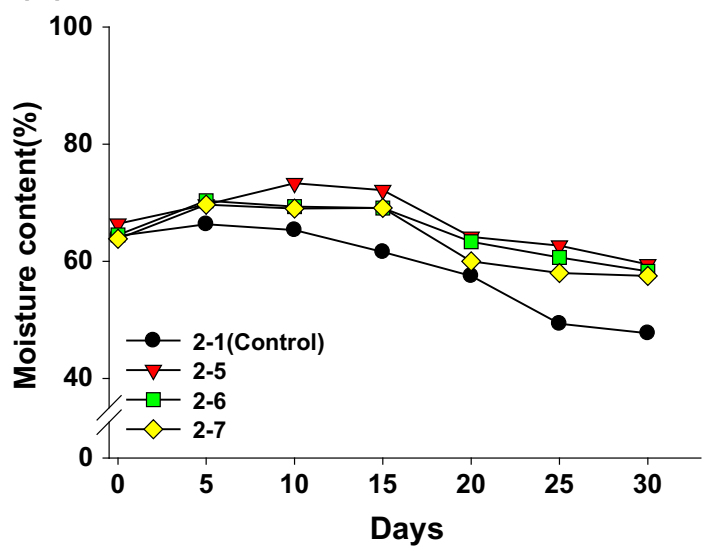

Fig. 3 MC content profiles during successive VW composting cycles. (A) 1st cycle with SD, (B) 2nd cycle with SD, (C) 1st cycle with CP, (D) 2nd cycle with $\mathrm{CP}$

microbial activity is decomposing organic/inorganic acids and, consequently, increasing release of ammonia from microbial mineralization activity $[18,23]$.

After 25 days of composting, the $\mathrm{pH}$ declined in all the reactors. A decrease in $\mathrm{pH}$ can occur when $\mathrm{NH}_{4}{ }^{+}-\mathrm{N}$ is volatilized because of decomposition and $\mathrm{H}^{+}$is released through nitrification by nitrifying bacteria [18, 24, 25]. Because the ratio of $\mathrm{NO}_{3}{ }^{-} / \mathrm{NH}_{4}{ }^{+}$was not determined in our study, we were unable to confirm the nitrification process in this experiment. However, as temperature was slightly increased from 25 to $30{ }^{\circ} \mathrm{C}$ after $20-30$ days in the first composting cycle (Fig. 2), we could assume that nitrification was occurred during maturation period.

For the second cycle of composting, the initial $\mathrm{pH}$ was high, in the ranges of 7.84-8.98 and 7.91-8.52 for the SD and $\mathrm{CP}$ mixtures (Fig. 4 B, D). The peak $\mathrm{pH}$ was 9.17 for reactor 2-2 at 25 days of mixing in the second cycle. Compared to the $\mathrm{pH}$ profile of the first cycle of composting in which $\mathrm{pH}$ varied about 3-4 unit, variance of the $\mathrm{pH}$ profile of the second cycle of composting was less than 1 units. Because no organic substrate (neither SD nor CP) was used in the second cycle, an initial low $\mathrm{pH}$ was not observed. Steady state of $\mathrm{pH}$ in the second cycle of composting could be interpreted that more resistant compounds such as cellulose, hemicellulose, and lignin were degraded and partly transformed to humus after decomposing easily breakdown compounds, monosaccharides, starch, lipids, etc. [26].

EC is another main parameter used for evaluating the compost process (Fig. 5). The initial EC of each mixture in the first compost cycle ranged 1.19-1.75 and 2.25-2.36 dS m${ }^{-1}$ for the $\mathrm{SD}$ and $\mathrm{CP}$ mixtures except control plot that composting process was not occurred due to decaying rather than decomposition. After 5 days of composting, EC value was slightly increased until 15 days, and then, EC value was decreased to $1.36-1.86$ and $1.90-2.65 \mathrm{dS} \mathrm{m}^{-1}$ for the SD and CP mixtures. In the early stage of composting, EC was increased because of microbial mineralization of organics and release of salt ions [27]. Huang et al. [24] also pointed out that EC can decrease 
(A)

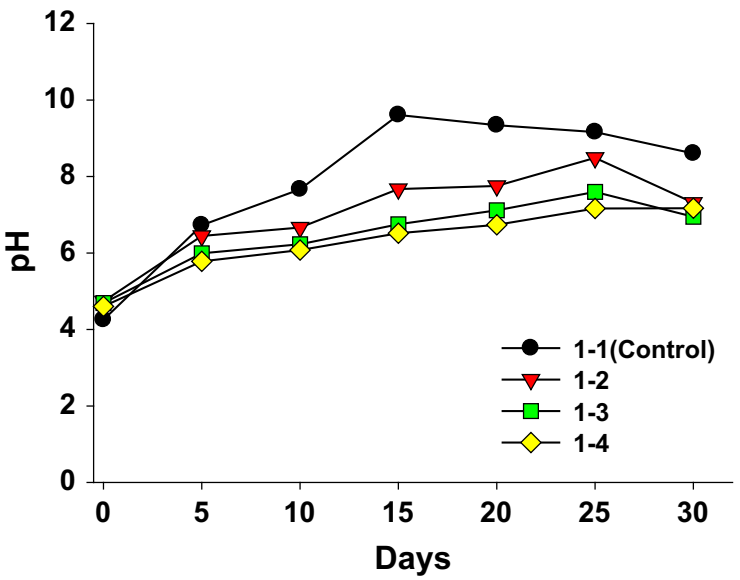

(C)

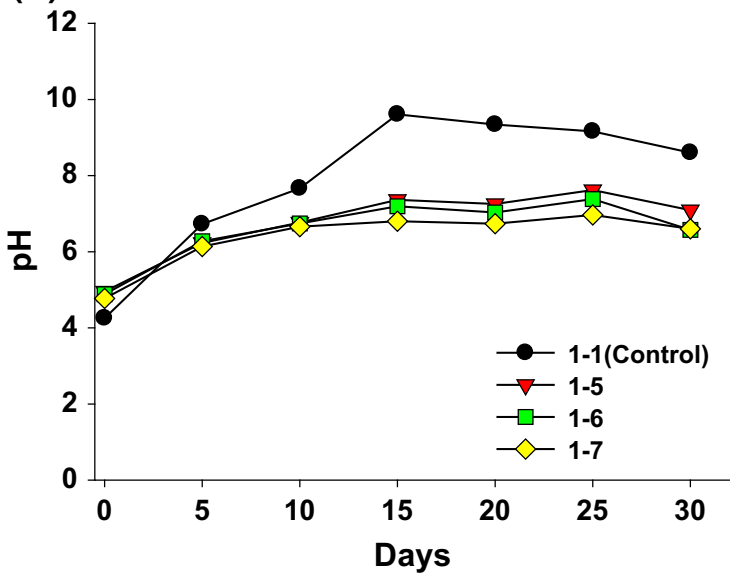

(B)

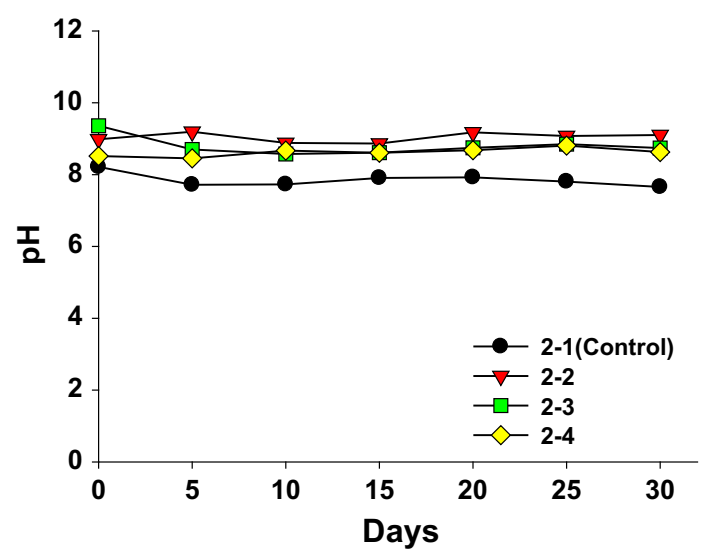

(D)

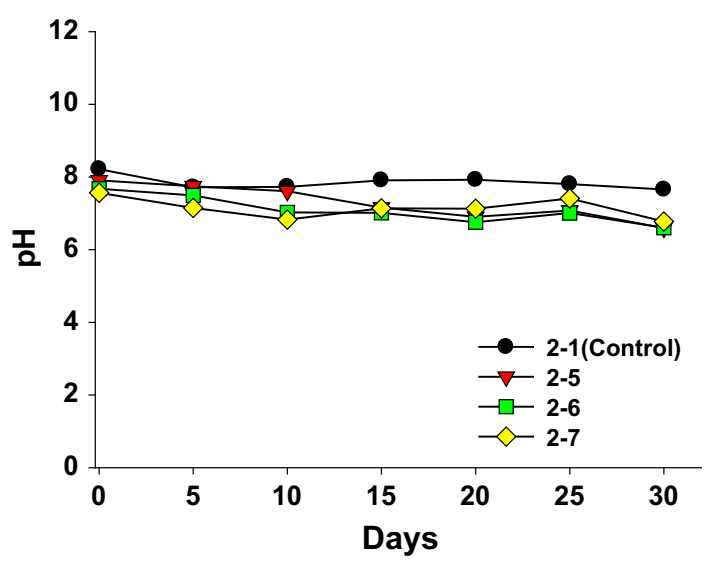

Fig. $4 \mathrm{pH}$ variations during successive VW composting cycles. (A) 1st cycle with SD, (B) 2nd cycle with SD, (C) 1 st cycle with CP, (D) 2nd cycle with $\mathrm{CP}$

Table 3 Chemical properties of the vegetable waste and bulking agents

\begin{tabular}{lllllll}
\hline Raw materials & Moisture content $(\%)$ & $\mathrm{pH}$ & $\left.\mathrm{EC}(\mathrm{dS} \mathrm{m})^{-1}\right)$ & $\mathrm{OM}(\%)$ & $\mathrm{TC}(\%)$ & TN $(\%)$ \\
\hline Vegetable waste (VW) & $79.54 \pm 0.38$ & $4.26 \pm 0.04$ & $4.74 \pm 0.11$ & $67.86 \pm 0.78$ & $53.01 \pm 3.55$ & $1.74 \pm 0.16$ \\
Sawdust (SD) & $29.76 \pm 0.35$ & $4.83 \pm 0.03$ & $0.24 \pm 0.01$ & $74.13 \pm 0.69$ & $61.03 \pm 3.26$ & $0.96 \pm 0.07$ \\
Cocopeat (CP) & $41.17 \pm 1.16$ & $5.86 \pm 0.06$ & $0.83 \pm 0.06$ & $55.02 \pm 1.36$ & $45.07 \pm 2.78$ & $1.23 \pm 0.09$ \\
\hline
\end{tabular}

when ammonia is volatilized and mineral salts are precipitated. After 25 days of composting, $\mathrm{pH}$ decreased in all the reactors, and ammonia volatilization was one of the reasons for this drop. This result matches with the decrease in EC due to ammonia volatilization.

In the second cycle of composting, different EC profiles were observed comparing to the first cycle. The initial average EC value was ranged $0.79-2.65 \mathrm{dS} \mathrm{m}^{-1}$ and increased to $1.36-2.86 \mathrm{dS} \mathrm{m}^{-1}$ after 35 days of composting, and higher EC values were observed when more VW was mixed. This result can be interpreted that the absence of bulking agents (SD or $\mathrm{CP}$ ) in the second composting cycle favored microbial activity to decompose the VW and more salt was released compared to the first composting cycle.

The optimum EC value for composting has been suggested by many researchers, and value was varied from less than 2 to $4 \mathrm{dS} \mathrm{m}^{-1}$, considering crop growth and phytotoxicity [28-30]. The EC value of final compost in our study was ranged $1.36-2.86 \mathrm{dS} \mathrm{m}^{-1}$, and those range of $\mathrm{EC}$ value satisfied the optimum range of EC in terms of crop growth and phytotoxicity. 
(A)

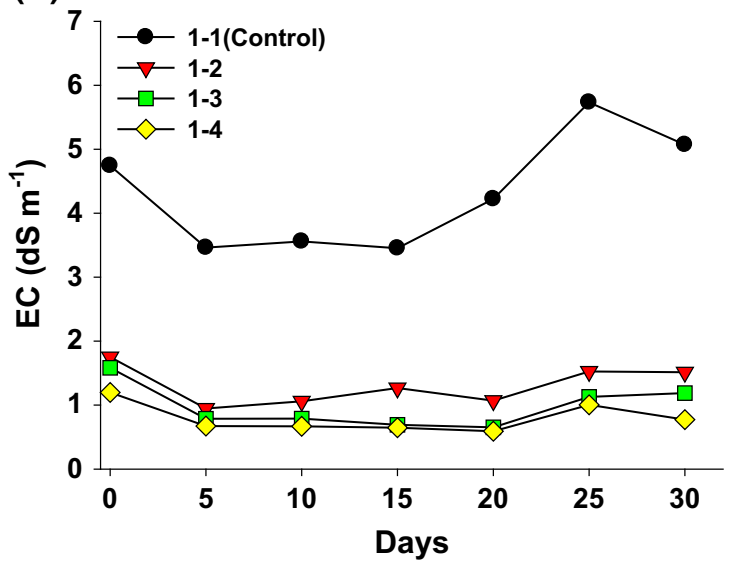

(C)

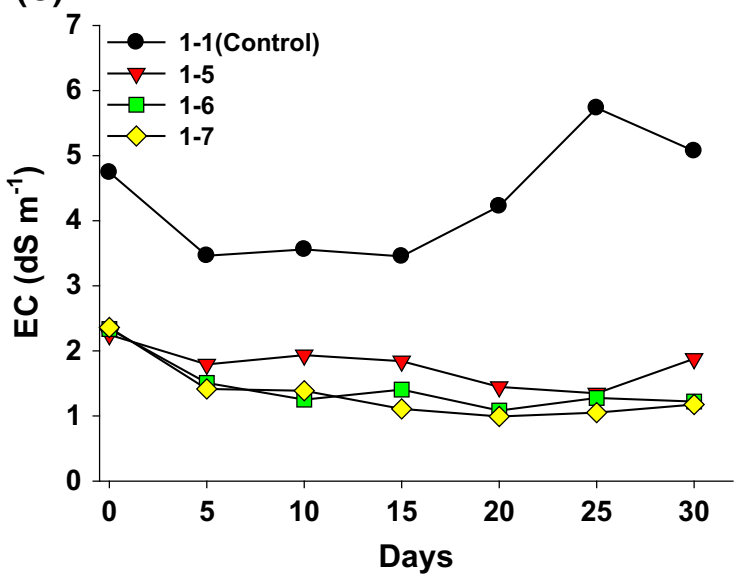

(B)

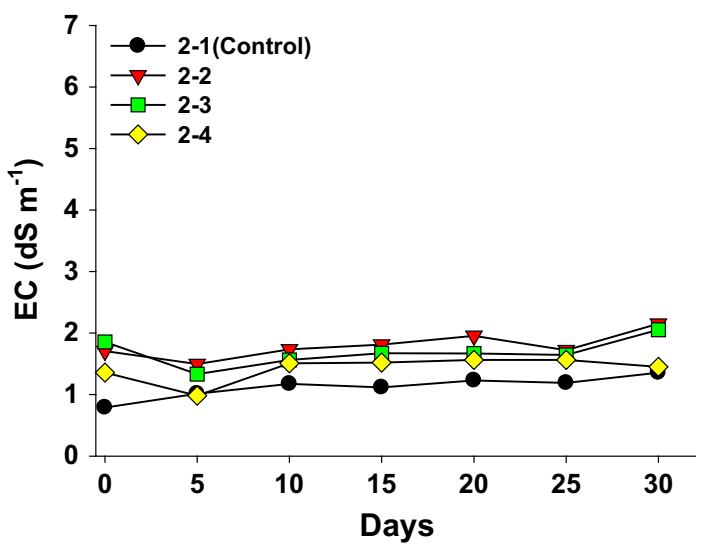

(D)

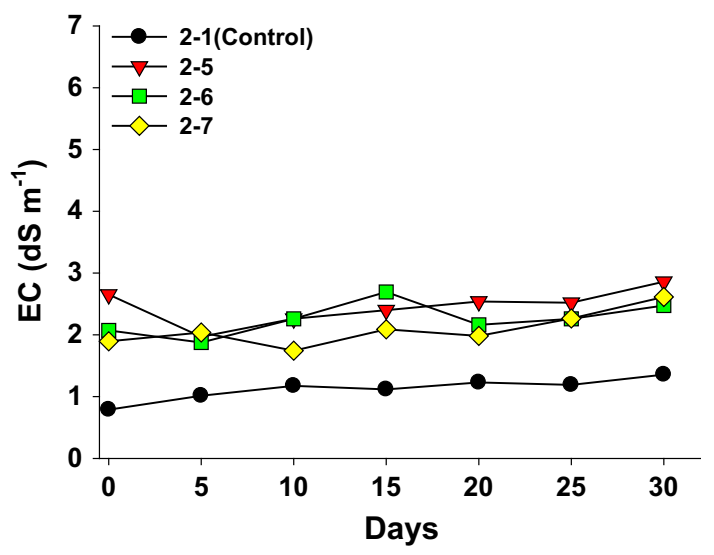

Fig. 5 EC variations during successive VW composting cycles. (A) 1st cycle with SD, (B) 2nd cycle with SD, (C) 1st cycle with CP, (D) 2nd cycle with $\mathrm{CP}$

\section{Change of $O M$ contents and $\mathrm{C} / \mathrm{N}$ ratio}

Organic matter $(\mathrm{OM})$ content is a major indicator for evaluating composting performance. Variations of $\mathrm{OM}$ content of each reactor for the first and second compost cycles are shown in Fig. 6. The OM contents of the initial SD and CP mixtures ranged 70.7-72.2 and 59.9-63.4\%. Both of the first and second cycle of composting, the OM content decreased gradually as composting was processed. The OM contents of the final products after the first and second composting cycles ranged 60.6-64.0 and $49.4-51.5 \%$ at the SD and CP treatments. This result can be explained that microorganisms consume saccharides, lipids, and amino acids in the early mesophilic phase and fungi degrade lignin and cellulose in the thermophilic phase causing decline of $\mathrm{OM}$ contents in the compost $[26,31]$.

$\mathrm{C} / \mathrm{N}$ ratio is an important factor for composting because it affects microbial activity. The optimal initial $\mathrm{C} / \mathrm{N}$ ratio for composting is 20-40 [18]. After the first compost cycle, the $\mathrm{C} / \mathrm{N}$ ratio of each mixture ranged $30.0-36.5$ for the $\mathrm{SD}$ mixtures and 23.2-29.3 for the CP mixtures (Table 4). The $\mathrm{C} / \mathrm{N}$ ratios of the SD mixtures were significantly higher than those of the $\mathrm{CP}$ mixtures, owing to the higher carbon content of SD $(61.0 \%)$ than of $\mathrm{CP}(45.0 \%)$. The $\mathrm{C} / \mathrm{N}$ ratio decreased during the first cycle because the volatilization of $\mathrm{CO}_{2}$ through carbon decomposition was greater than the loss of nitrogen in the $\mathrm{NH}_{3} / \mathrm{NH}_{4}{ }^{+}$form, especially in $\mathrm{SD}$ mixtures of high $\mathrm{C} / \mathrm{N}(30.0-36.5)$ [32]. In the second cycle, the $\mathrm{C} / \mathrm{N}$ ratios decreased in the same manner as those of the first cycle, but the decline was less. The $\mathrm{C} / \mathrm{N}$ ratio of each final compost ranged 19.1-21.8 and 18.4-20.1 for the SD and $\mathrm{CP}$ mixtures.

\section{Nutrient contents in the compost}

The nutrient contents including TN, available phosphorus $\left(\mathrm{P}_{2} \mathrm{O}_{5}\right)$, and potassium $\left(\mathrm{K}_{2} \mathrm{O}\right)$ of the compost are summarized in Table 4. TN of each treatment was ranged 1.5-1.9 and $1.6-2.2 \%$ in the first and second compost. Compared to 
(A)

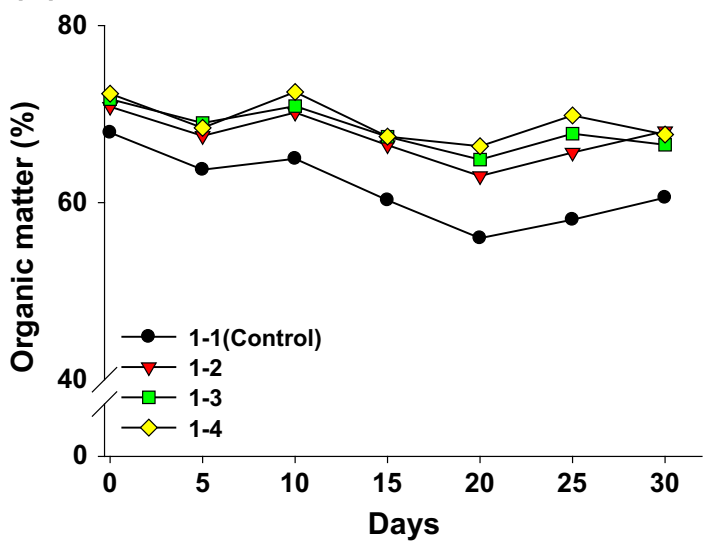

(C)

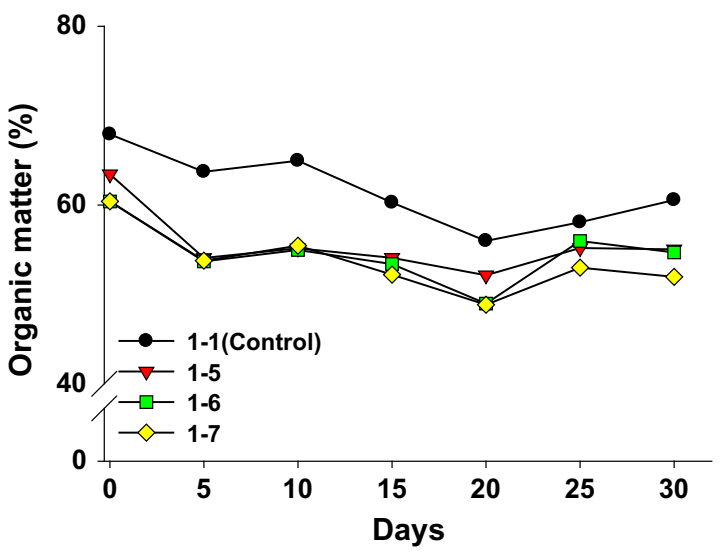

(B)

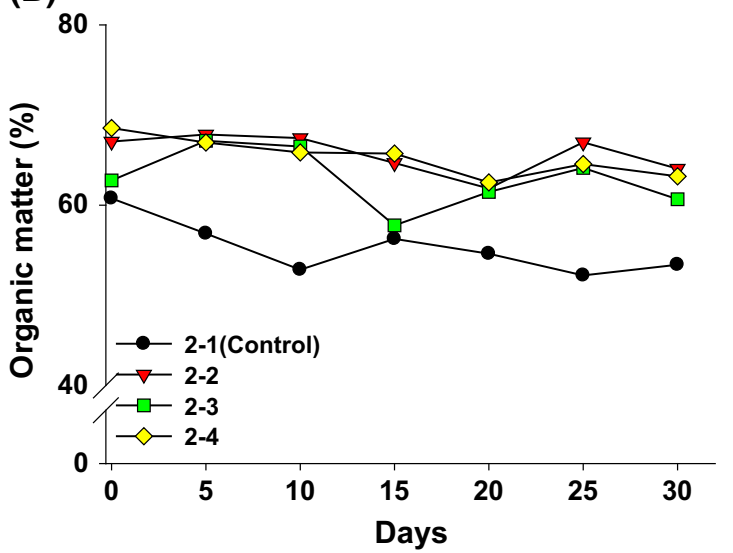

(D)

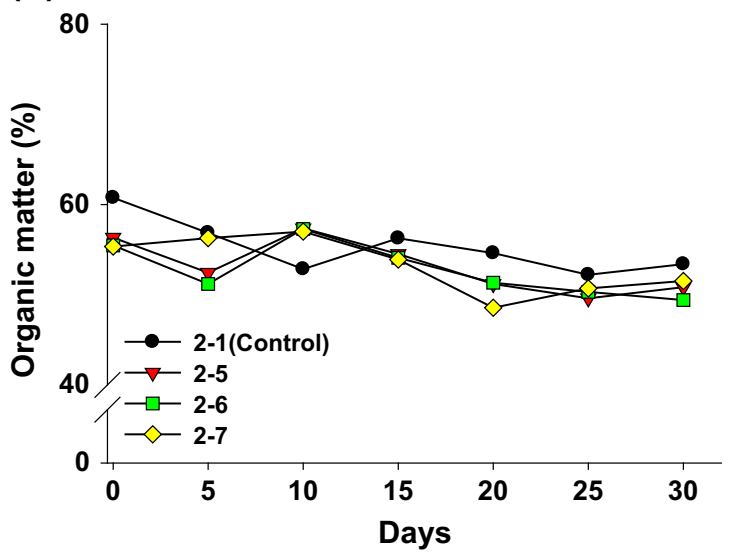

Fig. 6 OM content variations during successive VW composting cycles of (A) SD and (B) CP treatments

the first cycle of composting, TN was increased 9.4-32.9\% when 20 or $30 \%$ of VW was added in the second experiment. Sudharsan and Kalamdhad [33] reported that total nitrogen content is generally increased because of $\mathrm{N}$ mineralization and evaporation of moisture. Volatilization of $\mathrm{NH}_{3}{ }^{-}$is mostly occurred at the thermophilic phase (within 10 days) and increased temperature lowered MC in the compost. Although we did not measure composition ratio between $\mathrm{NH}_{4}-\mathrm{N}$ and $\mathrm{NO}_{3}-\mathrm{N}$ concentration, we could assume that the form of nitrogen in the final compost is considered as $\mathrm{NH}_{4}-\mathrm{N}$ form mostly. According to Wang et al. [25], high temperature during the early composting phase causes excessive $\mathrm{NH}_{3}$ emission. Also in our study, volatilization of $\mathrm{NH}_{3}$ was limited due to the closed condition of reactor. Therefore, excessive $\mathrm{NH}_{3}$ and high $\mathrm{pH}$ in the compost (7.56-8.98) could inhibit nitrification [34]. The concentration of available $\mathrm{P}\left(\mathrm{P}_{2} \mathrm{O}_{5}\right)$ and $\mathrm{K}\left(\mathrm{K}_{2} \mathrm{O}\right)$ in the final compost was not significantly different to the each plots except reactor 2-7 for available P (Table 4). However, increased concentration of $\mathrm{P}$ and $\mathrm{K}$ compared to reactor 2-1 was observed and the highest concentration of available $\mathrm{P}(0.57 \%)$ and $\mathrm{K}(0.58 \%)$ was observed when $30 \%$ of VW was added. Wei et al. [35] studied $\mathrm{P}$ fractionation of different organic wastes including fruit-vegetable waste (FVW) and reported that concentration of TP and available $\mathrm{P}$ of FVW was 0.33 and $0.10 \%$, respectively. Concentration of available $\mathrm{P}$ in our study was ranged $0.38-0.57 \%$ when more VW was added and those value was 4-6 times high. Since the concentration of $\mathrm{P}$ is fairly constant during the composting process [35] much higher concentration of available $\mathrm{P}$ in the second cycle of compost compared to the previous study could be input of additional VW in the second cycle of composting.

\section{Compost maturity, toxicity and heavy metal concentration}

To evaluate compost maturity and toxicity, a Solvita ${ }^{\circledR}$ maturity test and a germination test were conducted after finishing the second composting experiment. As shown in 


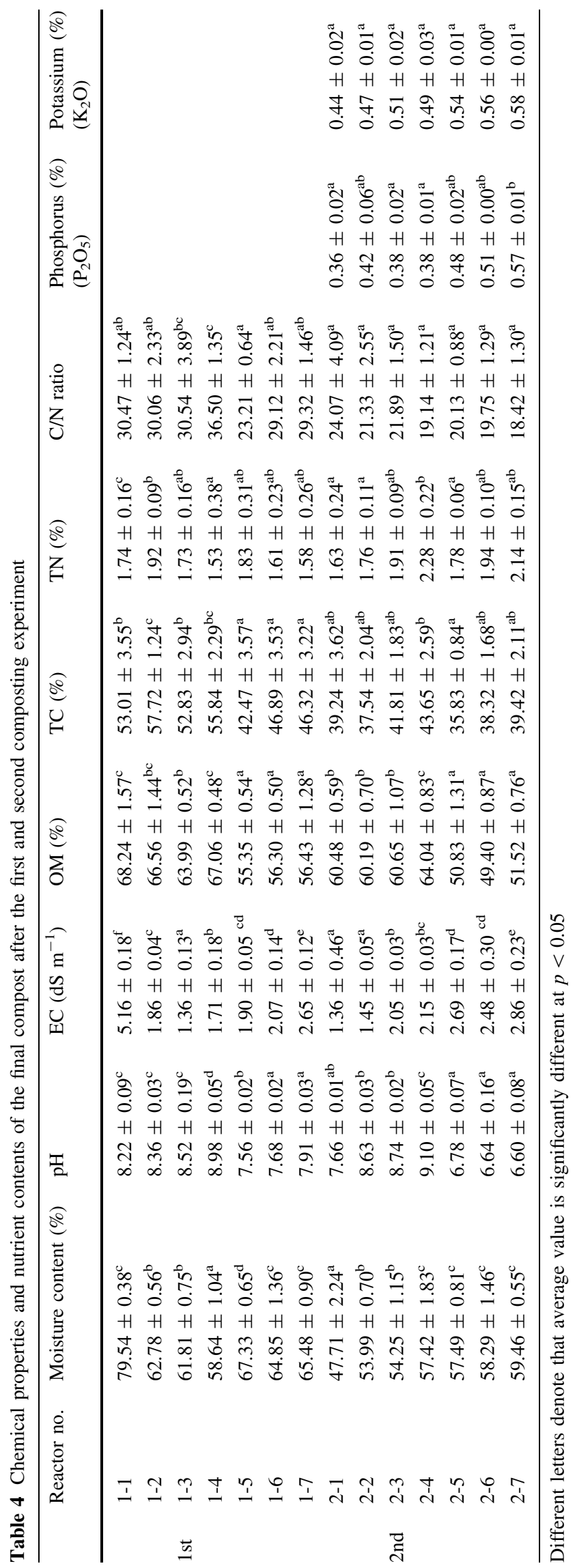




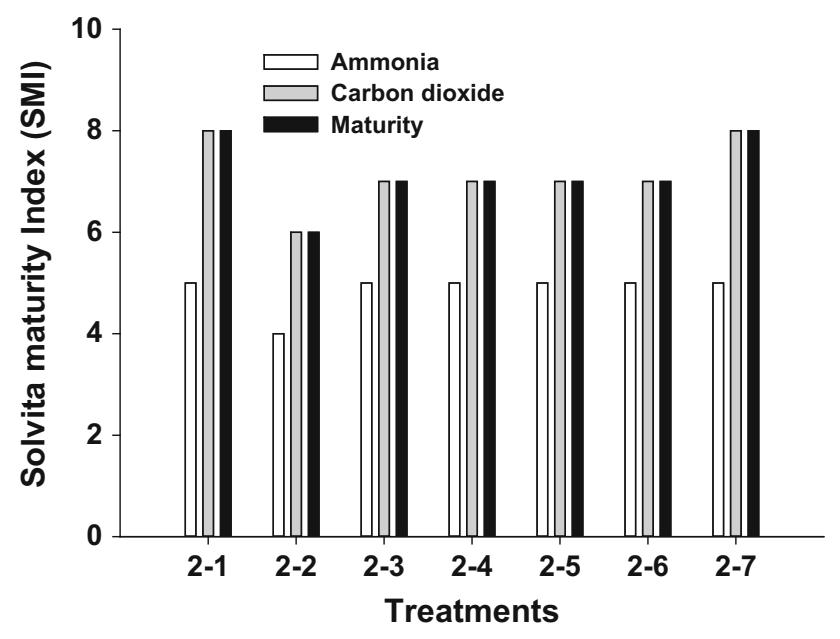

Fig. 7 Solvita maturity indices (SMI) of the final composts (SMI $>7$ indicates matured compost)

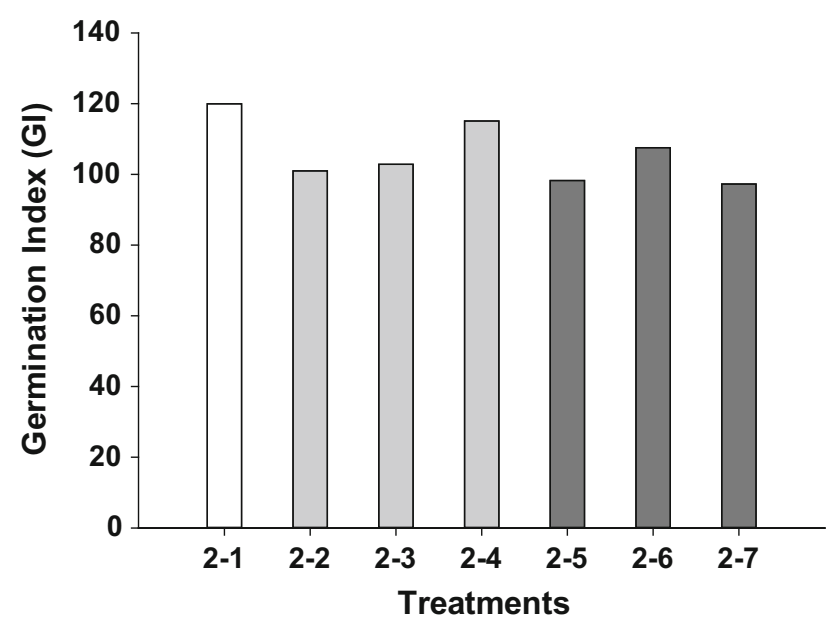

Fig. 8 Germination index (GI) of the final composts (GI $<80$ indicates matured compost)
Fig. 7, all the SMI value was over 7 except reactor 2-2. According to guideline of maturity test [17], compost is considered as finishing the late curing phase when the SMI is over 4, and compost is regarded as a matured compost when SMI is over 7. Since all the SMI was over 7 except reactor 2-2, all the compost could be regarded as a matured compost and compost in reactor 2-2 was at the late curing phase. Result of germination test in Fig. 8 also showed that all the GI was over 80, at the range of 97.19-101.93, and could be considered that all the compost had no adverse effect on plant growth and phytotoxicity.

Heavy metal concentration in the finished compost after the second composting experiment is shown in Table 5. All the heavy metal concentration was much lower than criteria set by Korean government indicating that all the manufactured compost had no concern of toxicity in terms of heavy metal concentration.

\section{Correlation of chemical parameters and toxicity index}

The results of bivariate correlation analysis between compost properties and toxicity index, GI, are shown in Table 6. Among other properties, only reduction in $\mathrm{OM}$ had a negative correlation with GI at $p<0.05$ meaning that GI value was low as reduction in OM contents was increased. This result can be concluded that OM contents were decreasing during composting processes because of microbial decomposition and lower OM contents had an adverse effect on the growth of root in the germination test.

However, no negative correlation with $\mathrm{EC}$ and $\mathrm{C} / \mathrm{N}$ ratio was observed in our study compared to other previous studies. When EC value is high (greater than $10 \mathrm{dS} \mathrm{m}^{-1}$ ), soluble ions or salinity can cause phytotoxicity. In addition, low or high $\mathrm{C} / \mathrm{N}$ ratio can cause either ammonium toxicity or $\mathrm{N}$ immobilization [36]. The $\mathrm{EC}$ value of the final

Table 5 Heavy metal concentration in the final compost (unit $\mathrm{mg} \mathrm{kg}^{-1}$ )

\begin{tabular}{llllllll}
\hline Reactor no. & $\mathrm{Pb}$ & $\mathrm{Ni}$ & $\mathrm{Cu}$ & $\mathrm{Zn}$ & $\mathrm{As}$ & $\mathrm{Cr}$ \\
\hline $2-1$ & $0.07 \pm 0.02$ & $2.20 \pm 0.07$ & $3.96 \pm 0.04$ & $14.95 \pm 0.08$ & $0.24 \pm 0.03$ & $3.93 \pm 0.56$ & $0.01 \pm 0.00$ \\
$2-2$ & $0.07 \pm 0.00$ & $1.96 \pm 0.08$ & $4.50 \pm 0.14$ & $27.90 \pm 0.04$ & $0.16 \pm 0.06$ & $4.01 \pm 0.64$ & $0.01 \pm 0.00$ \\
$2-3$ & $0.05 \pm 0.00$ & $1.87 \pm 0.33$ & $3.53 \pm 0.32$ & $22.86 \pm 0.26$ & $0.05 \pm 0.01$ & $3.04 \pm 0.62$ & $0.01 \pm 0.00$ \\
$2-4$ & $0.05 \pm 0.00$ & $1.71 \pm 0.23$ & $3.54 \pm 0.33$ & $19.81 \pm 0.25$ & $0.03 \pm 0.01$ & $5.25 \pm 0.79$ & $0.01 \pm 0.00$ \\
$2-5$ & $0.04 \pm 0.00$ & $1.90 \pm 0.10$ & $3.91 \pm 0.19$ & $22.52 \pm 0.11$ & $0.21 \pm 0.03$ & $4.00 \pm 0.83$ & $0.00 \pm 0.00$ \\
$2-6$ & $0.03 \pm 0.01$ & $2.15 \pm 0.13$ & $3.47 \pm 0.01$ & $17.22 \pm 0.16$ & $0.29 \pm 0.09$ & $7.67 \pm 0.83$ & $0.01 \pm 0.00$ \\
$2-7$ & $0.04 \pm 0.00$ & $2.35 \pm 0.02$ & $4.02 \pm 0.07$ & $18.09 \pm 0.16$ & $0.17 \pm 0.02$ & $9.98 \pm 1.11$ & $0.01 \pm 0.00$ \\
Threshold value & 130 & 45 & 360 & 900 & 45 & 200 & 5 \\
\hline
\end{tabular}


Table 6 Correlation of chemical properties and germination index in final compost after finishing the second composting experiment

\begin{tabular}{lll}
\hline & & Germination index \\
\hline OM losses & Pearson correlation & $-655^{*}$ \\
& $p$ value & 0.011 \\
C/N ratio & Pearson correlation & 0.364 \\
& $p$ value & 0.200 \\
$\mathrm{pH}$ & Pearson correlation & 0.159 \\
& $p$ value & 0.586 \\
$\mathrm{EC}$ & Pearson correlation & -187 \\
& $p$ value & 0.522 \\
$\mathrm{MC}$ & Pearson correlation & 0.462 \\
& $p$ value & 0.096 \\
\hline
\end{tabular}

*Correlation is significant at $p<0.05$

compost in our study was $1.36-2.86 \mathrm{dS} \mathrm{m}^{-1}$ indicating that concentration of soluble ions or salts was in the range of non-phytotoxic for GI. Also, $\mathrm{C} / \mathrm{N}$ value of the final compost (18.42-21.89) was within the optimal range (12-25) for microbial activity $[37,38]$.

Acknowledgments We gratefully acknowledge the financial support of "Technology for establishing quality standards of food waste compost and evaluation in its application to agriculture (Project No. PJ010925)" from the Rural Development Administration, Republic of Korea.

\section{References}

1. Chen SS, Iris KM, Tsang DC, Yip AC, Khan E, Wang L, Poon CS (2017) Valorization of cellulosic food waste into levulinic acid catalyzed by heterogeneous Brønsted acids: temperature and solvent effects. Chem Eng J 327:328-335

2. Igalavithana AD, Lee SE, Lee YH, Tsang DC, Rinklebe J, Kwon EE, Ok YS (2017) Heavy metal immobilization and microbial community abundance by vegetable waste and pine cone biochar of agricultural soils. Chemosphere 174:593-603

3. MOE (Ministry of Environment) (2016) National survey of waste production and treatment. http://webbook.me.go.kr/DLi-File/091/ 025/003/5631055.pdf. Accessed 15 July 2017 (in Korean)

4. MAFRA (Ministry of Agriculture, food and rural affairs) (2016) yearly book of agro-market. https://www.kamis.or.kr/customer/ board/board_file.do?brdno $=4 \&$ brdctsno $=424628 \&$ brdctsfileno $=$ 8451. Accessed 19 July 2017 (in Korean)

5. Gondek K, Kopec M, Mierzwa M, Tabak M, Chmiel M (2014) Chemical and biological properties of composts produced from organic waste. J Elementol 19(2):377-389

6. Huang GF, Wu QT, Wong JWC, Nagar BB (2006) Transformation of organic matter during co-composting of pig manure with sawdust. Biores Technol 97(15):1834-1842

7. Epstein E (1996) The science of composting, 1st edn. CRC Press, Boca Raton

8. Forte A, Fagnano M, Fierro A (2017) Potential role of compost and green manure amendment to mitigate soil GHGs emissions in
Mediterranean drip irrigated maize production systems. Environ Manag 192:68-78

9. Morales AB, Bustamante MA, Marhuenda-Egea FC, Moral R, Ros M, Pascual JA (2016) Agri-food sludge management using different co-composting strategies: study of the added value of the composts obtained. J Clean Prod 121:186-197

10. Ntougias S, Papadopoulou KK, Zervakis GI, Kavroulakis N, Ehaliotis C (2008) Suppression of soil-borne pathogens of tomato by composts derived from agro-industrial wastes abundant in Mediterranean regions. Biol Fertil Soils 44(8):1081-1090

11. Vallini G, Pera A, Valdrighi M, Cecchi F (1993) Process constraints in source-collected vegetable waste composting. Water Sci Technol 28(2):229-236

12. Zhang J, Zeng G, Chen Y, Yu M, Yu Z, Li H, Huang H (2011) Effects of physico-chemical parameters on the bacterial and fungal communities during agricultural waste composting. Bioresour Technol 102(3):2950-2956

13. Yu H, Zeng G, Huang H, Xi X, Wang R, Huang D, Li J (2007) Microbial community succession and lignocellulose degradation during agricultural waste composting. Biodegrad 18(6):793-802

14. Rawoteea SA, Mudhoo A, Kumar S (2017) Co-composting of vegetable wastes and carton: effect of carton composition and parameter variations. Bioresour Technol 227:171-178

15. Viaene J, Agneessens L, Capito C, Ameloot N, Reubens B, Willekens K, De Neve S (2017) Co-ensiling, co-composting and anaerobic co-digestion of vegetable crop residues: product stability and effect on soil carbon and nitrogen dynamics. Sci Hortic 220:214-225

16. USCC (USA Composting Council) (2002) Test methods for the examination of composting and compost. US Composting Council, Ronkonkoma

17. Woods End Laboratories, Inc. (2012) Official Solvita ${ }^{\circledR}$ guideline: compost emissions test V 7.0 Update. http://www.agrolan.co.il/ UploadProductFiles/compost_manual.pdf. Accessed 16 July 2017

18. Onwosi CO, Igbokwe VC, Odimba JN, Eke IE, Nwankwoala MO, Iroh IN, Ezeogu LI (2017) Composting technology in waste stabilization: on the methods, challenges and future prospects. J Environ Manag 190:140-157

19. Vuorinen AH, Saharinen MH (1997) Evolution of microbiological and chemical parameters during manure and straw co-composting in a drum composting system. Agricult Ecosyst Environ 66(1):19-29

20. Mohammad N, Alam MZ, Kabbashi NA, Ahsan A (2012) Effective composting of oil palm industrial waste by filamentous fungi: a review. Resour Conserv Recycl 58:69-78

21. Bernal MP, Alburquerque JA, Moral R (2009) Composting of animal manures and chemical criteria for compost maturity assessment. A review. Bioresour Technol 100(22):5444-5453

22. Petric I, Helić A, Avdić EA (2012) Evolution of process parameters and determination of kinetics for co-composting of organic fraction of municipal solid waste with poultry manure. Bioresour Technol 117:107-116

23. Jolanun B, Towprayoon S (2010) Novel bulking agent from clay residue for food waste composting. Bioresour Technol 101(12):4484-4490

24. Huang GF, Wong JWC, Wu QT, Nagar BB (2004) Effect of C/N on composting of pig manure with sawdust. Waste Manag 24(8):805-813

25. Wang Y, Pang L, Liu X, Wang Y, Zhou K, Luo F (2016) Using thermal balance model to determine optimal reactor volume and insulation material needed in a laboratory-scale composting reactor. Bioresour Technol 206:164-172

26. Tuomela M, Vikman M, Hatakka A, Itävaara M (2000) Biodegradation of lignin in a compost environment: a review. Bioresour Technol 72(2):169-183 
27. Shah MC, Kansara JC, Shilpkar PG (2015) Composting of Calotropis Gigantea leaves in presence of sheep dung. Curr World Environ 10(1):281

28. Turan NG (2008) The effects of natural zeolite on salinity level of poultry litter compost. Bioresour Technol 99(7):2097-2101

29. Yang F, Li G, Shi H, Wang Y (2015) Effects of phosphogypsum and superphosphate on compost maturity and gaseous emissions during kitchen waste composting. Waste Manage 36:70-76

30. Zhang L, Sun X (2016) Improving green waste composting by addition of sugarcane bagasse and exhausted grape marc. Bioresour Technol 218:335-343

31. Zhang L, Zeng G, Dong H, Chen Y, Zhang J, Yan M, Huang Z (2017) The impact of silver nanoparticles on the co-composting of sewage sludge and agricultural waste: evolutions of organic matter and nitrogen. Bioresour Technol 230:132-139

32. Al-Bataina BB, Young TM, Ranieri E (2016) Effects of compost age on the release of nutrients. Int. Soil Water Conserv Res 4(3):230-236
33. Sudharsan VV, Kalamdhad AS (2015) Evolution of chemical and biological characterization during thermophilic composting of vegetable waste using rotary drum composter. Int J Environ Sci Technol 12(6):2015-2024

34. Caceres R, Malinska K, Marfa O (2018) Nitrification within composting: a review. Waste Manage 72:119-137

35. Wei Y, Zhao Y, Xi B, Wei Z, Li X, Cao Z (2015) Changes in phosphorus fractions during organic wastes composting from different sources. Bioresour Technol 189:349-356

36. Tiquia SM (2010) Reduction of compost phytotoxicity during the process of decomposition. Chemosphere 79(5):506-512

37. Jimenez EI, Carcia VP (1992) Determination of maturity indices for city refuse composts. Agr Ecosyst Environ 38(4):331-343

38. Brewer LJ, Sullivan DM (2003) Maturity and stability evaluation of composted yard trimmings. Compost Sci Util 11(2):96-112 